

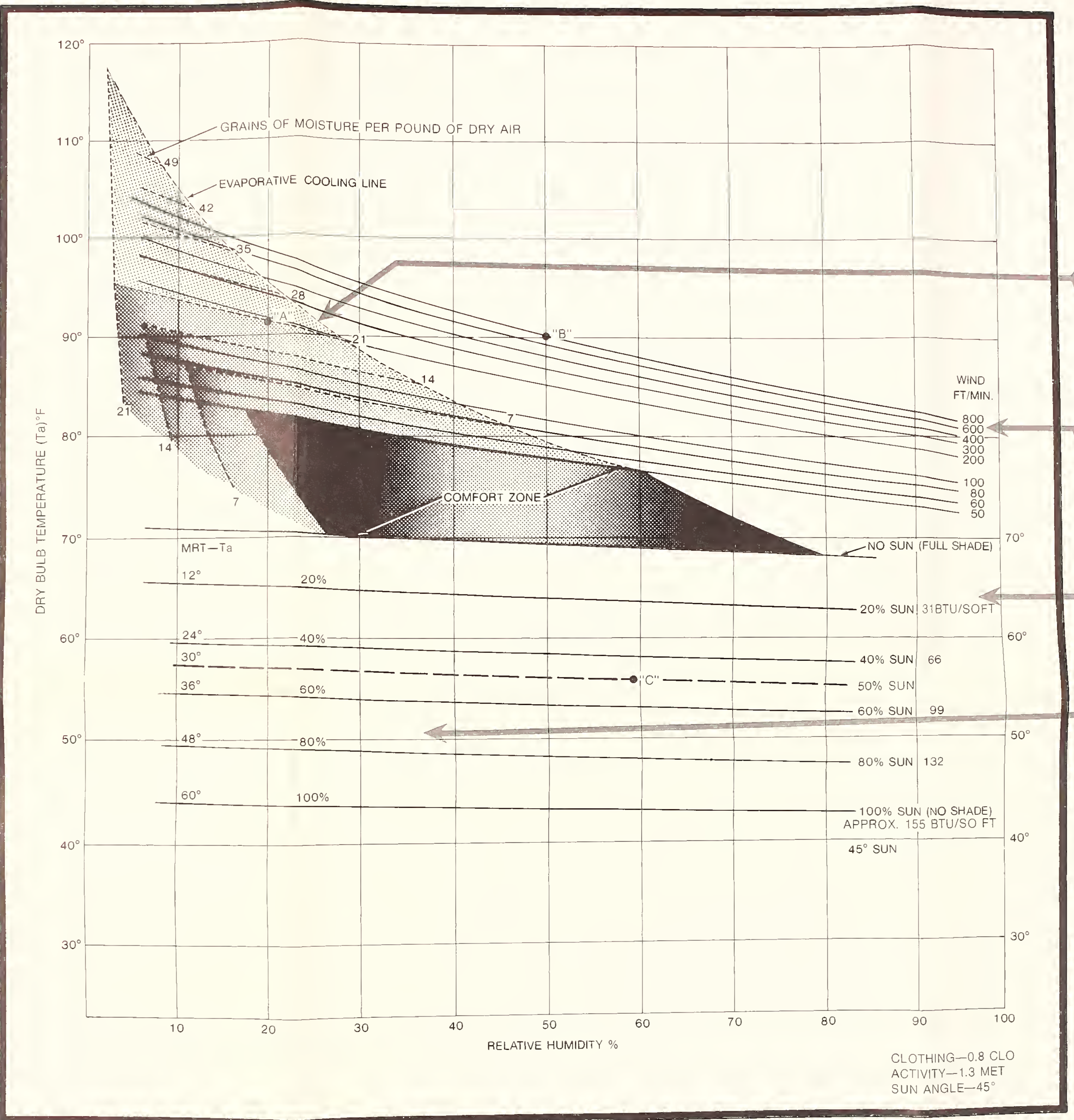

DESIGN STEPS

A. Overlay the comfort chart with the average daily tem-
perature and humidity amplitudes for selected months

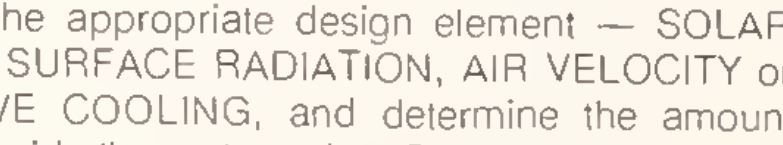

needed to provide thermal comfort. See examples at each

C. Utilize natural forces to provide needed radiation
Coporative cooling or ventilation, and supplement these

EVAPORATIVE COOLING

High temperatures and low the comfort zone in "siill ai" by treating the air with a evaporative cooler ading, on the average, 21 grains o

AIR VELOCITY

can be comfortable if the relative humidity is not high an lines describe the upper limits of comfort at various

Example: Point " $B "$ ", 90 "F and $50 \%$ R.H., is comtorlable

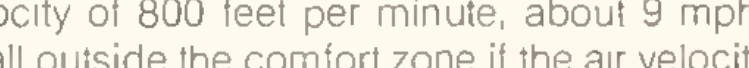

SOLAR RADIATION

Temperatures as low as the middle forties are comforiable provide shading as required to avoid overheating.

SURFACE RADIATION

Surtaces that are warmer than the surrounding air te

Surtaces that are warmer than the surrounding air te
perature can have a warming eftect similar to the sun. Th

and air temperature is shown on the chart as MRT-Ta.

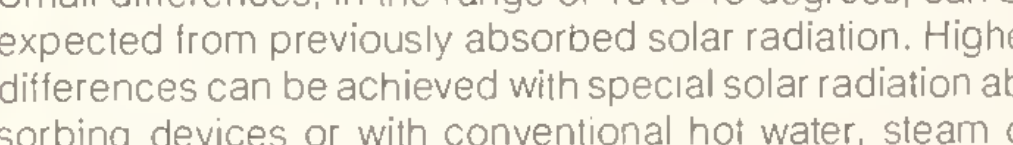

ectric resistance heater

Example: Again at Point "C," $56^{\circ}$ and $60 \mathrm{RH}$, is comtortab emperature (MRT) is $30.5^{\circ} \mathrm{F}$ above the air temperature

be required, since it would be impractioat to heat all sur

Dr. Preston MCNall
Porter Driscoll, Al

Center for Building Technology National Bureau of Standards
Washong

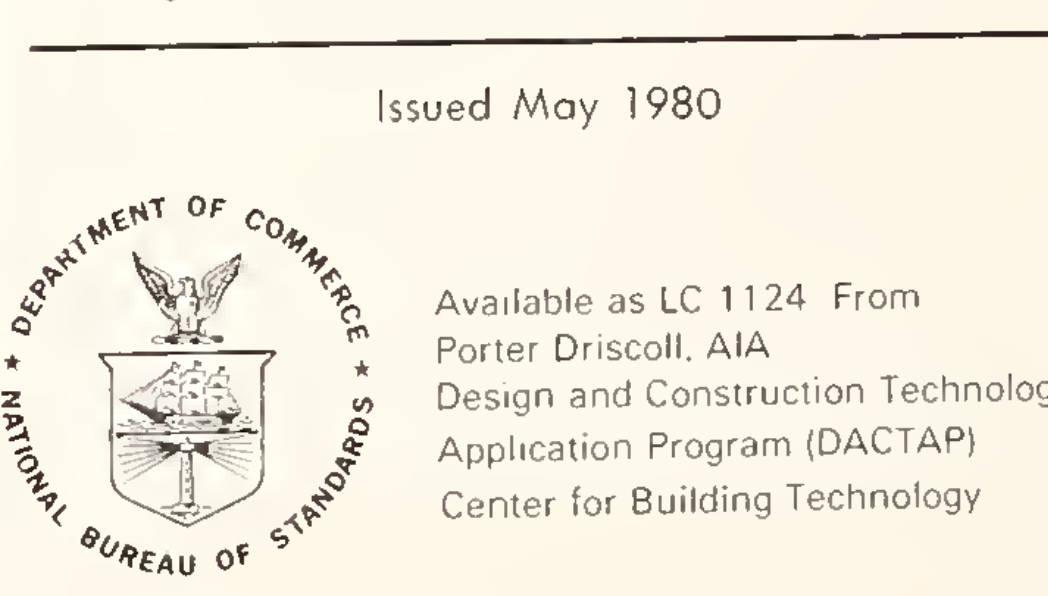

\section{BIOCLIMATIC CHART}

U.S. DEPARTMENT OF COMMERCE hilip M. Klutznick, Secretary Jordan $J$. Baruch, Assistant Secretary
for Productivity, Technology and Innovation NATIONAL BUREAU OF STANDARDS 
